\title{
KESIAPAN DAERAH MENUJU JAWA BARAT SMART PROVINCE
}

\author{
Diana Sari $^{1}$, Didit Praditya ${ }^{2}$, C. Suprapti Dwi Takariani ${ }^{3}$ \\ ${ }^{1,2,3}$ Balai Pengembangan Sumber Daya Manusia dan Penelitian Komunikasi dan Informatika Bandung \\ Jl. Pajajaran No. 88, Bandung, Jawa Barat, 40173, Indonesia \\ No. Telp./HP: ${ }^{1} 081910022310,{ }^{2} 08157723727,{ }^{3} 08122179515$ \\ E-mail:1dian010@kominfo.go.id, ${ }^{2}$ didi012@ kominfo.go.id, ${ }^{3} \operatorname{csup} 001 @$ kominfo.go.id
}

Naskah diterima pada tanggal 5 September 2019 direvisi tanggal 3 Oktober 2019 disetujui tanggal 18 Oktober 2019

\section{REGIONAL READINESS FOR JAWA BARAT SMART PROVINCE}

\begin{abstract}
The West Java Provincial Government initiated West Java Smart Province (JSP), which began with Jabar Cyber Province. In its development, the concept of smart province developed at the provincial level, and it was interpreted at the regional level so that there were views from regions related to JSP. Therefore, it is necessary to look at other perspectives of the smart province from the local perspective as an enrichment for the province to obtain a comprehensive description of JSP implementation from the local government's side and how the readiness of the region towards JSP. This study uses a qualitative approach, with three critical aspects of concern in smart province, namely: governance, infrastructure, and ICT services/applications in each region. This readiness was described descriptively from data and information through interviews with informants in six areas. The results of the analysis provide an overview of the readiness of each region in West Java towards JSP. The readiness of Banjar City, Garut Regency, and Purwakarta Regency are the change from manual to digital, and development of ICT infrastructure and service, although it is still partial. Meanwhile, Bogor City, Cimahi City, and Cirebon Regency readiness is a developed ICT-based service even though development between services are doing separately, but data sharing has been carried out.
\end{abstract}

Keywords: West Java, smart province, governance, infrastructure, services.

\begin{abstract}
Abstrak. Pemerintah Provinsi Jawa Barat menginisiasi Jawa Barat Smart Province (JSP) yang diawali dengan Jabar Cyber Province. Dalam perkembangannya, konsep berkembang di tingkat provinsi dan diinterpretasi di tingkat daerah, sehingga ada pandangan-pandangan dari daerah yang muncul terkait JSP. Oleh karena itu perlu ditinjau smart province dari sudut pandang daerah sebagai pengayaan bagi provinsi dalam implementasi JSP, agar diperoleh gambaran secara komprehensif dari sisi penyelenggara pemerintahan terhadap JSP serta bagaimana kesiapan daerah menuju JSP. Penelitian ini menggunakan pendekatan kualitatif, dengan tiga aspek penting yang menjadi perhatian dalam smart province, yaitu: tata kelola, infrastruktur, dan layanan/aplikasi TIK di masing-masing wilayah. Gambaran kesiapan ini diuraikan secara deskriptif dari data dan informasi melalui wawancara kepada informan di enam wilayah. Hasil analisis memberikan gambaran kesiapan masing-masing wilayah di Jawa Barat menuju JSP. Kesiapan Kota Banjar, Kabupaten Garut, dan Kabupaten Purwakarta yaitu adanya perubahan dari manual ke digital serta sudah ada pengembangan infrastruktur dan layanan TIK walaupun masih parsial. Sementara itu, kesiapan Kota Bogor, Kota Cimahi, dan Kabupaten Cirebon yaitu telah dikembangkan layanan berbasis TIK walaupun pengembangan antarlayanan masih ada yang dilakukan secara terpisah, namun sudah dilakukan sharing data.
\end{abstract}

Kata kunci: Jawa Barat, smart province, tata kelola, infrastruktur, layanan. 


\section{PENDAHULUAN}

Perkembangan Teknologi Informasi dan Komunikasi (TIK) menyentuh aspek penyelenggaraan pemerintahan. Dampak dari perkembangan tersebut banyak dirasakan oleh instansi pemerintah terutama dalam meningkatkan pelayanan publik (Kumar, 2014; Barlow, 2015; Kementerian Ristek dan Pendidikan Tinggi dalam Salsabila, 2015). Secara administratif dan geografis, wilayahwilayah pemerintahan yang ada memiliki kondisi dan permasalahan yang beragam, di antaranya transportasi, lingkungan, kesehatan, pendidikan, energi, dan sebagainya (Puslitbang PPI, 2013; Kementerian Kominfo, 2015). Menghadapi hal tersebut, banyak wilayah merasa perlu menyediakan respon yang tanggap terhadap kondisi yang ada serta memahami kebutuhan di wilayah tersebut dengan mengoptimasi penggunaan TIK.

Penggunaan TIK tidak hanya ditujukan untuk efisiensi pada proses bisnis dan meningkatkan pelayanan publik. Lebih jauh dari itu, pada akhirnya untuk menciptakan kondisi masyarakat yang nyaman dan sesuai dengan kebutuhannya. Kondisi wilayah seperti ini mengarah kepada smart region dengan pengembangan dimensi lainnya, antara lain: smart government, smart transportation, smart health, smart energy, smart environment, smart surveillance, smart people, dan lainnya (Kominfo, 2013; Kumar, 2014; Stimmel, 2016), hal ini juga mendorong wilayah-wilayah di Indonesia mengembangkan smart region.

Pemerintah Provinsi (Pemprov) Jawa Barat merupakan salah satu pemerintahan yang saat ini terus melakukan berbagai inovasi untuk mewujudkan Provinsi Jawa Barat yang smart dengan harapan terwujudnya pelayanan prima kepada masyarakat, dalam arti pelayanan yang cepat, tepat, adil, dan akuntabel. Penyempurnaan terhadap sistem pelayanan publik yang menyangkut perbaikan metode dan prosedur pelayanan publik dilakukan pihak Pemprov Jawa Barat. Untuk mewujudkan harapan tersebut penerapan dan pengembangan Teknologi Informasi dan Komunikasi (TIK) dilakukan dengan Program Jabar Cyber
Province yang diluncurkan pada tahun 2008 sebagai salah satu upaya dalam memberikan layanan kepada publik (Budhirianto, 2014; Abdurrahman, 2016).

Jabar Cyber Province merupakan program unggulan dan merupakan langkah awal menuju Program Jabar Smart Province (Diskominfo Provinsi Jabar, 2014). Program Jabar Cyber Province mengintegrasikan inisiatif-inisiatif TIK di Provinsi Jawa Barat. Tujuannya: (1) menghubungkan secara digital semua instansi pemerintah provinsi, dengan harapan aparatur dapat bekerja dengan mudah, cepat, tepat, efektif, hemat, sehingga dapat melaksanakan tugas pokoknya dengan baik; (2) melakukan transformasi digital atas proses-proses bisnis pemerintah provinsi; dan (3) memperkenalkan e-literacy dan fasilitas TIK yang terjangkau untuk masyarakat, dengan bantuan TIK, dibayangkan masyarakat akan hidup lebih mudah, misalnya, dalam hal kesehatan, dengan cepat mereka dapat memperoleh seperti kemudahan mendapat informasi, kemudahan menyelesaikan berbagai urusan, murah dalam proses pembiayaan. Kemudian dalam hal perbankan, masyarakat dapat terbantu dengan kemudahan berbisnis dan bertransaksi, sehingga hidupnya terbantu dalam hal kemudahan urusan (e-business). Selain itu juga masyarakat agar dapat dicerdaskan pengetahuan dan wawasannya dengan kemudahan akses informasi (e-education) (Diskominfo Provinsi Jabar, 2014; Budhirianto, 2014). Program tersebut juga merupakan upaya dari Pemerintah Provinsi Jawa Barat untuk mengurangi atau menghilangkan kesenjangan digital dan target mewujudkan masyarakat informasi di Provinsi Jawa Barat.

Dari sisi implementasi pengembangan TIK di instansi pemerintah (e-government), Jawa Barat memiliki peringkat kedua secara nasional (Buku Putih TIK Kominfo, 2015) dengan rata-rata 3,06 (dalam melakukan pemeringkatan e-government ini digunakan skala 1 sampai dengan 4 dengan angka 1 menunjukkan penilaian sangat kurang, sampai dengan 4 maka kategori yang disandang daerah tersebut adalah sangat baik). Dilihat dari keseluruhan aspek yang dinilai, aspek kebijakan merupakan dimensi 
yang masih di bawah rata-rata dimensi lainnya.

Perkembangan Jabar Cyber Province ini terus berlangsung dan terminologinya dilanjutkan dengan target selanjutnya mewujudkan Jabar Smart Province (JSP) yang diinisiasi pada tahun 2016. Dalam rangka memberikan pelayanan publik yang lebih baik, Pemerintah Provinsi Jawa Barat berupaya untuk mewujudkan Program Jabar Smart Province, yang ditujukan untuk memberikan pelayanan berbasis digital kepada masyarakat sehingga program menjadi lebih efisien dan transparan, terutama di bidang pendidikan, kesehatan, infrastruktur, dan lainnya (Kepala Dinas Komunikasi Informatika Provinsi Jawa Barat, Anton Gustoni, dalam Abdurrahman, 2016). Inisiasi ini diawali dengan penerapan smart government yang merupakan langkah selanjutnya dari penerapan e-government, yang dapat mendukung pembangunan smart city di wilayah Provinsi Jawa Barat (Diskominfo Provinsi Jabar, 2014; Diskominfo Provinsi Jabar, 2017).

Insisiasi Jabar Smart Province dimulai oleh provinsi, oleh sebab itu perlu melihat bagaimana daerah sebagai elemen yang akan mengimplementasi untuk menuju ke smart province memahami arah program melalui kesiapan daerah agar program JSP dapat berjalan selaras dengan tujuan JSP. Sehingga kesiapan implementasi perlu diidentifikasi, mengacu pada kesiapan dilihat dari tata kelola, infrastruktur TIK, dan layanan. Kesiapan ini dilihat dari tingkat kematangan layanan yang diadopsi dari model smart city dengan memandang kota/kabupaten sebagai unit pembentuk smart province (provinsi terdiri dari kota/kabupaten, dipandang sebagai "city").

\section{LANDASAN KONSEP}

\section{Pengembangan Smart City dan Smart Government}

Pengembangan smart city di Indonesia masih dilakukan secara silo dan sporadis, sebagian besar mengadopsi model sesuai kebutuhan dan pemahaman masing-masing. Sejauh ini, sudah ada kebijakan pengembangan perkotaan yang tertuang dalam Dokumen Kebijakan dan Strategi Perkotaan Nasional (KSPN) dan juga kebijakan untuk pengembangan perdesaan tetapi memang belum mendefinisikan secara spesifik mengenai pengembangan kota/desa yang "smart" (BAPPENAS, 2011; PPN/Bappenas, 2015). Konsep-konsep "smart" lebih banyak di dorong dari industri, akademisi, asosiasi/komunitas antara lain: Smarter Planet (IBM), Smart and Connect (Cisco), Garuda Smart City (Suhono, 2015 dalam Kementerian Kominfo, 2015; Stimmel, 2016), Smart Sustainable Cities (ITU), dan lainnya (Puslitbang PPI, 2013; Kementerian Kominfo, 2015).

Secara umum, terminologi "smart" lebih banyak berkembang kepada "smart city", istilah smart city mendefinisikan lingkungan perkotaan baru, salah satu yang dirancang untuk meningkatkan kinerja dengan TIK dan bentuk lain dari modal fisik. Dengan pengelolaan sumber daya yang efektif dan cerdas, dengan harapan bahwa kota akan mendorong kualitas hidup yang lebih tinggi bagi warga negara, dan meningkatkan kondisi ekonomi (Stimmel, 2016). Konsep lainnya mengenai smart city adalah kota dengan konsep memanfaatkan teknologi informasi dan komunikasi secara terintegrasi dalam setiap program pemerintah untuk menangani masalah perkotaan (Suhono, 2015 dalam Kementerian Kominfo, 2015; SCCIC, 2018). Pemanfaatan TIK pada proses pengembangan dan pengelolaan smart city adalah menghubungkan, memonitor dan mengendalikan berbagai sumber daya di kota dengan lebih efektif dan efisien untuk memaksimalkan pelayanan kepada warganya serta mendukung pembangunan yang berkelanjutan.

Fokus pengembangan smart city utamanya masih di dominasi pada peran infrastruktur TIK, tetapi banyak juga yang sudah mengembangkan tidak hanya pada aspek infrastruktur saja dengan melihat aspek tata kelola dan layanan (Stimmel, 2016; Purnomo, Meyliana \& Prabowo, 2016). Gambaran implementasi smart city di beberapa negara, di antaranya di Jepang dengan komponen smart city yang diimplementasikan smart community, smart 
healthcare, smart creative industry, smart automobile traffic system, smart agriculture, smart robots. Freiburg Green City dengan eco housing, car-free streets, kota yang didesain untuk orang bukan untuk mobil, jalur pejalan kaki, jalur sepeda, dan trem merupakan sarana utama yang dikembangkan dalam perencanaan kota, selain perlindungan terhadap iklim, solar power, dan program daur ulang. Smart City Bristol, dengan komponen yang diimplementasikan smart energy, smart transport, smart data, eksplorasi tantangan dan kesempatan lain di bidang sosial dan ekonomi seperti tele-health, dan sebagainya (Kominfo, 2013; Kementerian Kominfo, 2015).

Gil-Garcia et.al. dalam Anthopoulos \& Reddick (2016), menyimpulkan bahwa beberapa definisi smart city menggambarkan fenomena yang sama, yaitu pemanfaatan infrastruktur dan layanan berbasis TIK untuk meningkatkan cara hidup perkotaan (urban), serta memiliki beberapa komponen dan subelemen yang terdiri dari: (1) teknologi dan data (TIK, data, dan informasi); (2) lingkungan fisik (lingkungan alam dan infrastruktur perkotaan); (3) masyarakat (ekonomi berbasis pengetahuan, SDM, dan tata kelola pemerintahan); dan pemerintahan (penataan institusi, administrasi/pemerintah kota, dan pelayanan publik). Oleh karena itu, pemerintahan merupakan salah satu komponen smart city yang memiliki sub-elemen: penataan institusi, pemerintahan kota, dan pelayanan publik. Terkait hubungan antara smart city dan tata kelola pemerintahan, Anthopoulos \& Reddick (2016) menyatakan bahwa smart city berhubungan dangan inovasi yang kebanyakan walaupun tidak harus berbasis TIK, dapat meningkatkan cara hidup perkotaan (urban) di aspek: manusia, tata kelola pemerintahan, ekonomi, mobilitas, lingkungan dan cara hidup dengan fokus pengembangan smart city berkaitan dengan aspek tata kelola, infrastruktur dan layanan/aplikasi (Puslitbang PPI, 2013; Barlow, 2015; Stimmel, 2016; Purnomo, Meyliana \& Prabowo, 2016).

Selanjutnya, Anthopoulos \& Reddick (2016) menggunakan metodologi riset kajian literatur dengan kata kuci "smart" dan "government", untuk mengkaji lebih lanjut hubungan antara smart government dan smart city, didapatkan beberapa pengertian seperti yang disajikan pada Tabel 1 berikut.

Tabel 1

Definisi Relatif Smart Government

\begin{tabular}{|c|c|c|}
\hline Istilah & Definisi & Sumber Kutipan \\
\hline $\begin{array}{l}\text { Smart } \\
\text { Government dan }\end{array}$ & Smart city adalah area praktik untuk smart government. & $\begin{array}{l}\text { Nam \& Pardo } \\
\text { (2011) }\end{array}$ \\
\hline \multirow[t]{3}{*}{ Smart City } & $\begin{array}{l}\text { Smart government merupakan sumber dari pelayanan publik pintar, dari } \\
\text { pemerintah kota dan keterlibatan publik (masyarakat). }\end{array}$ & $\begin{array}{l}\text { Anthopoulos \& } \\
\text { Reddick (2016) } \\
\text { Anthopoulos, } \\
\text { Mavridis, } \\
\text { Giannakidou (2015) }\end{array}$ \\
\hline & Smart city adalah suatu area untuk pembangunan smart government. & $\begin{array}{l}\text { Anthopoulos, } \\
\text { Reddick (2016) }\end{array}$ \\
\hline & $\begin{array}{l}\text { Smart government berurusan dengan pemerintahan smart city, yang } \\
\text { mengelola dan menerapkan kebijakan dengan mengangkat/meningkatkan } \\
\text { TIK dan institusi serta secara aktif terlibat dan berkolaborasi dengan } \\
\text { pemangku kepentingan. }\end{array}$ & $\begin{array}{l}\text { Scholl \& Alawadhi } \\
\text { (2016) }\end{array}$ \\
\hline
\end{tabular}

Sumber: Anthopoulos \& Reddick, 2016.

Smart government berkomplementer dan saling berhubungan dengan smart city. Smart government tidak mengesampingkan smart city, namun smart government memberi arah pembangunan smart city, seraya menggunakan smart city sebagai area praktik, mis. kolaborasi dan pengujian 108 layanan bersama (Gil-Garcia, Zhang \& Puron-Cid, 2016; Anthopoulos \& Reddick, 2016).

\section{Konsep Smart Province di Indonesia}

Istilah smart province di Indonesia muncul dari masing-masing daerah dengan 
kesamaan fokus pengembangan awal di $e$ government. Secara umum lebih banyak menekankan bagaimana menyediakan layanan kepada masyarakat dan mengintegrasikan pelayanan dengan memanfaatkan TIK (Pemprov Riau, 2017; Pemprov Sumatera Utara, 2017; Diskominfo
Provinsi Jabar, 2014). Pemprov menginisiasi langkah menuju smart city dengan penerapan e-government, hal ini terkait dengan peran langsung pemerintah dalam penyelenggaraan pemerintahan dan area yang lebih awal dapat diimplementasi.

Tabel 2

Komparasi Arah Pengembangan Smart province di Indonesia

\begin{tabular}{lll}
\hline \multicolumn{1}{c}{ Provinsi } & \multicolumn{1}{c}{ Overview } & Fokus \\
Riau Smart & Pemerintah dapat memanfaatkan kecanggihan teknologi informasi dan aplikasi e-gov \\
Province & digital untuk memaksimalkan pelayanan publik. Untuk menuju provinsi cerdas, \\
& sejumlah aplikasi pengelolaan daerah dibuka secara transparan ke publik dan bisa \\
& diakses di portal resmi Pemprov Riau di riau.go.id. Tujuannya, untuk \\
& penyebarluasan informasi dan pelayanan publik. \\
Sumut Smart & Provinsi Sumatera Utara menjadi provinsi dengan layanan berbasis IT, sehingga e-gov \\
Province & lebih memudahkan masyarakat. Untuk menuju hal tersebut dengan \\
Jabar Smart & mengintegrasikan pelayanan lintas SKPD, instansi maupun kabupaten/kota. \\
Province & Memberikan pelayanan terbaik bagi masyarakat yang berbasis digital, sehingga e-gov \\
& program menjadi lebih efisien dan transparan, terutama di bidang pendidikan, smart \\
& kesehatan, infrastruktur, dan lainnya. Tujuannya supaya masyarakat Jawa Barat
\end{tabular}

Sumber: Sintesis informasi web mengenai smart province di Indonesia (Abdurrahman, 2016; Pemprov Riau, 2017; Pemprov Sumatera Utara, 2017).

\section{Aspek Pengembangan Smart Province dan Komparasi Kesiapan Smart Province}

Aspek pengembangan smart region sinergis terhadap tumbuhnya smart city (Mayangsari \& Novani, 2015; Utomo, 2016) sehingga smart province sebagai bagian pengembangan wilayah dapat diharmonisasi dengan mendorong perkembangan smart city. Berdasarkan relasi smart city dan smart government, ada beberapa aspek penting sebagai landasan smart city, yaitu tata kelola (Mayangsari \& Novani, 2015; Utomo, 2016), infrastruktur TIK dan layanan/aplikasi (Barlow, 2015; Stimmel, 2016; Purnomo, Meyliana \& Prabowo, 2016).

Kesiapan daerah dapat dilihat dari gambaran kematangan aspek tata kelola, infrastruktur TIK dan layanan/aplikasi yang diadopsi dari model smart city dengan memandang kota/kabupaten sebagai unit pembentuk smart province (Provinsi terdiri dari kota/kabupaten, dipandang sebagai "city") yang disusun terdiri dari 5 bagian (Puslitbang PPI, 2013) yaitu: (1) Nonexistent, kota-kota pada bagian ini adalah kota yang masih belum ada inisiasi untuk melakukan pengembangan smart city. Karakteristik dari pengembangan layanan TIK adalah masih tahap migrasi dari manual data menuju ke digital data. (2) Initialized, pada bagian ini, pemerintah kota sudah melakukan inisiatif untuk mengembangkan layanan smart city walaupun pengembangan masih dilakukan secara parsial. Karakteristik dari lapisan ini adalah adanya sharing data yang dilakukan secara parsial. (3) Scattered, kota-kota yang mempunyai komitmen penuh dalam mengembangkan layanan smart city walaupun pengembangan antarlayanan masih dilakukan secara terpisah. Pada tingkat ini, inisiatif masih dilakukan oleh struktur departemen/dinas sebagai serangkaian proyek terpisah dengan dinas/departemen lain. Karakteristik dari lapisan ini adalah sudah mulai dilakukan 
sharing data. (4) Integrated, inisiatif terkoordinasi jauh lebih baik, mencari sinergi untuk peningkatan dan tata kelola portofolio proyek yang lebih kolaboratif. Pada lapisan ini nilai yang disampaikan oleh inisiatif lebih besar. Karakteristik bagian ini sudah adanya valuable information yang merupakan hasil data analitis dari sharing data lintas dinas/departemen. (5) Smarter city, pada bagian ini, inisiatif pengembangan smart city merupakan bagian dari holistik master plan yang dikelola oleh pemerintah kota yang berdedikasi, termasuk warga dan bisnis.

\section{METODE PENELITIAN}

Penelitian ini bersifat deskriptif dengan menggunakan pendekatan kualitatif dengan melakukan pendalaman isu spesifik yang dipilih secara holistik dari setiap permasalahan yang menjadi pertanyaan penelitian. Informan ditentukan secara purposive, dengan pertimbangan informan tersebut yang mengetahui kondisi dan perkembangan bidang yang menjadi isu dalam penelitian ini. Informan dalam penelitian ini seperti terlihat pada Tabel 3.

Teknik pengumpulan data dilakukan melalui wawancara mendalam, yaitu menggali informasi dari para informan dengan menggunakan panduan dan pedoman wawancara. Focus Group Discussion (FGD) dilakukan untuk mengonfirmasi data di lapangan dan merumuskan kesiapan daerah menuju Jabar Smart Province.

Tabel 3

Informan Penelitian

\begin{tabular}{|c|c|}
\hline No & Informan \\
\hline 1 & $\begin{array}{l}\text { Kepala Dinas Komunikasi, Informatika, Statistik, dan Persandian Pemkot Bogor, Kepala Dinas Komunikasi } \\
\text { dan Informatika Kabupaten Cirebon, Kepala Dinas Komunikasi dan Informatika Kabupaten Garut, Kepala } \\
\text { Dinas Komunikasi, Informatika, Kearsipan dan Perpustakaan Kota Cimahi, Kepala Dinas Komunikasi dan } \\
\text { Informatika Kabupaten Purwakarta, Kepala Dinas Perhubungan, Komunikasi dan Informatika Banjar. }\end{array}$ \\
\hline 2 & $\begin{array}{l}\text { Kepala Dinas Kependudukan dan Catatan Sipil Kota Bogor, Kabupaten Cirebon, Kabupaten Garut, Kota } \\
\text { Cimahi, Kabupaten Purwakarta, Kota Banjar. }\end{array}$ \\
\hline 3 & $\begin{array}{l}\text { Kepala Dinas Pendidikan Kota Bogor, Kabupaten Cirebon, Kabupaten Garut, Kota Cimahi, Kabupaten } \\
\text { Purwakarta, Kota Banjar. }\end{array}$ \\
\hline 4 & $\begin{array}{l}\text { Kepala Dinas Kesehatan Kota Bogor, Kabupaten Cirebon, Kabupaten Subang, Kota Cimahi, Kabupaten } \\
\text { Purwakarta, Kota Banjar. }\end{array}$ \\
\hline 5 & $\begin{array}{l}\text { Kepala Dinas Koperasi dan PKM Kabupaten Cirebon, Kepala Dinas Koperasi dan UMKM Kota Bogor, } \\
\text { Kepala Dinas Koperasi dan UMKM Kabupaten Garut, Kepala Dinas Koperasi UMKM Perindustrian } \\
\text { Perdagangan dan Pertanian Kota Cimahi, Kepala Dinas Koperasi, UMKM, Kepala Perindag Kabupaten } \\
\text { Purwakarta, Kepala Dinas Perindustrian, Perdagangan, dan Koperasi Kota Banjar. }\end{array}$ \\
\hline 6 & $\begin{array}{l}\text { Kepala Bappeda Kabupaten Cirebon, Kota Bogor, Kabupaten Garut, Kota Cimahi, Kabupaten Purwakarta, dan } \\
\text { Kota Banjar. }\end{array}$ \\
\hline 7 & Perwakilan masyarakat di enam kabupaten/kota yang menjadi sampel lokasi penelitian. \\
\hline
\end{tabular}

Penentuan lokasi penelitian didasarkan pada Peraturan Menteri Komunikasi dan Informatika RI Nomor 13 Tahun 2016 tentang Hasil Pemetaan Urusan Pemerintahan Daerah di Bidang Komunikasi dan Informatika (Kementerian Kominfo, 2016). Pemetaan urusan pemerintahan Bidang Kominfo dilihat dari tingkat intensitas dan beban kerja yang dikategorikan menjadi tiga yakni besar, sedang, dan kecil. Provinsi Jawa Barat terdiri dari 27 kabupaten dan kota, ada 13 kabupaten dan kota yang masuk dalam kategori besar, 12 kabupaten dan kota yang masuk kategori sedang, dan 2 (dua) kabupaten dan kota yang masuk kategori kecil. Lokasi penelitian terpilih secara proporsional mewakili wilayah di Jawa Barat, lihat Tabel 4.

Indikator kesiapan daerah merujuk kepada tiga aspek penting yaitu tata kelola, bagaimana gambaran kebijakan/regulasi, 
organisasi TIK; infrastruktur, dengan gambaran jangkauan akses, jaringan antarPD, kapasitas; layanan/aplikasi, dengan gambaran layanan publik yang sudah berjalan, gambaran integrasi layanan, variansi layanan yang dilakukan (Puslitbang PPI, 2013; Purnomo, Meyliana \& Prabowo, 2016).

Tabel 4

Lokasi Penelitian

\begin{tabular}{cll}
\hline No & Nama Kabupaten/Kota & Kategori \\
\hline 1 & Kabupaten Cirebon & Besar \\
2 & Kabupaten Garut & Besar \\
3 & Kota Bogor & Besar \\
4 & Kabupaten Purwakarta & Sedang \\
5 & Kota Cimahi & Sedang \\
6 & Kota Banjar & Kecil \\
\hline
\end{tabular}

Pengolahan data dilakukan dengan koding data, klasifikasi data sesuai dengan karakteristik data, dan indikator masingmasing untuk diintegrasikan serta observasi terhadap indikator yang menjadi perhatian serta telusur dokumen pendukung. Pengintegrasian data kualitatif bukan dimaksud untuk mengeneralisasi data, tetapi memetakan isu yang berkaitan dengan kesiapan daerah menuju Jabar Smart
Province. Selanjutnya dilakukan analisis secara deskriptif terhadap konsep dan gambaran kesiapan daerah menuju Jabar Smart Province berdasarkan hasil koding data. Kategorisasi untuk kesiapan daerah berdasarkan adopsi dari framework tingkat kematangan/kesiapan, yaitu deskripsi terhadap suatu kondisi wilayah dengan ciri seperti pada tabel berikut.

Tabel 5

Kategorisasi Kesiapan Daerah Menuju Jabar Smart Province

\begin{tabular}{ll}
\hline Kategori & Gambaran Kota/Kabupaten \\
\hline Non- & Kota/Kab pada kategori ini adalah kota yang masih belum ada inisiasi untuk melakukan \\
Existent & pengembangan berbasis TIK. Karakteristik dari pengembangan layanan TIK adalah masih tahap \\
migrasi dari manual data menuju ke digital data. & \\
Initialized & $\begin{array}{l}\text { Kota/Kab sudah melakukan inisiatif untuk mengembangkan layanan berbasis TIK walaupun } \\
\text { pengembangan masih dilakukan secara parsial. Karakteristik dari kategori ini adalah adanya sharing } \\
\text { data yang dilakukan secara parsial. }\end{array}$ \\
Kcattered & $\begin{array}{l}\text { Kota/Kab yang mempunyai komitmen penuh dalam mengembangkan layanan berbasis TIK walaupun } \\
\text { pengembangan antarlayanan masih dilakukan secara terpisah. Pada tingkat ini, inisiatif masih } \\
\text { dilakukan oleh struktur departemen/dinas sebagai serangkaian proyek terpisah dengan } \\
\text { dinas/departemen lain. Karakteristik dari kategori ini adalah sudah mulai dilakukan sharing data. }\end{array}$ \\
Integrated & $\begin{array}{l}\text { Pada kategori ini, inisiatif terkoordinasi jauh lebih baik, mencari sinergi untuk peningkatan dan tata } \\
\text { kelola yang lebih kolaboratif. Karakteristik dari kategori ini adalah sudah adanya valuable information } \\
\text { yang merupakan hasil data analitis dari sharing data lintas dinas/departemen. }\end{array}$ \\
& $\begin{array}{l}\text { Pada kategori ini, inisiatif pengembangan smart city/smart region merupakan bagian dari holistic } \\
\text { masterplan yang dikelola oleh pemerintah, termasuk warga dan swasta. Pada kategori ini, layanan }\end{array}$ \\
& smart city dapat diakses kapan saja, di mana saja dan oleh siapa saja.
\end{tabular}

\section{HASIL PENELITIAN DAN PEMBAHASAN}

Kesiapan daerah menuju Jabar Smart Province (JSP) memberikan informasi gambaran kota/kabupaten menuju JSP. Sementara untuk gambaran kesiapan dilihat dari tiga aspek utama yaitu tata kelola, infrastruktur, dan layanan. Adapun gambaran secara detail dirumuskan dalam Tabel 6 yaitu gambaran kesiapan dari masing-masing wilayah sampel dari aspek tata kelola, infrastruktur TIK, dan layanan/aplikasi. 
Tabel 6

Gambaran Kesiapan Daerah Menuju JSP

Gambaran Kesiapan

\begin{tabular}{ccc}
\hline Tata Kelola & Infrastruktur & Layanan \\
\hline Kota Cimahi &
\end{tabular}

a) Payung hukum untuk melaksanakan implementasi TIK melalui Pedoman

a) Sudah terintegrasi, Diskominfo mengawal PD (tidak sendiri-sendiri)

Pengembangan e-Government di Lingkungan Pemerintah Kota Cimahi dan turunannya.

b) Untuk penerapan e-gov di Kota Cimahi, berawal dari Cimahi Cyber, dari tahun 2002. Rencana Pembangunan Jangka Menengah Daerah (RPJMD) Kota Cimahi Tahun 2012 - 2017; Rencana Pembangunan Jangka Panjang Daerah (RPJP) Kota Cimahi Tahun 2005 - 2025; Pedoman Pengembangan e-Government di Lingkungan Pemerintah Kota Cimahi; Keputusan Walikota Cimahi tentang Pembentukan Tim Informasi Teknologi (IT) Kota Cimahi; Kebijakan Tata Kelola Pengamanan Data Center; Kebijakan Tata Kelola Aplikasi e-Government; Kebijakan Tata Kelola dan Integrasi Data; persiapan adopsi sistem manajemen keamanan informasi berbasis iso 27001; dokumen perencanaan sistem keamanan jaringan berbasis firewall;

c) Masterplan TIK Kota Cimahi mengarah pada pengembangan sistem monitoring kota terintegrasi;

d) Dari Bappeda ada perencanaan pembangunan, dari unsur RW ada musyawarahnya hingga kelurahan b) Jaringan LAN lingkup perkantoran Pemkot Cimahi sudah menggunakan backbone fiber optik.

c) Jaringan WAN berbasis fiber Optic meliputi PD di luar area Perkantoran Pemerintah Kota Cimahi (Setwan, 3 Kecamatan, 15 Kelurahan, 11 Puskesmas, Perpustakaan Umum Kota Cimahi)

d) Jaringan CCTV Kewilayahan berbasis fiber optic meliputi 16 titik pantau berjumlah seluruhnya 54 kamera CCTV milik Dinas Perhubungan, Satuan Pol. PP. dan Diskominfoarpus

e) Jaringan CCTV pelayanan 25 titik pantau meliputi (Pelayanan Publik di Gedung Pemprov, 12 Kelurahan, 3 Kecamatan dan 8 Puskesmas Jaringan Layanan Informasi di Kelurahan, Puskesmas (digital signage) meliputi seluruh kecamatan, 12 kelurahan dan 8 puskesmas. berbasis fiber optic meliputi a) Pengembangan aplikasi diarahkan kepada penggunaan data secara bersama-sama (terintegrasi). Data sudah terpusat dan beberapa layanan saling terintegrasi, sisanya sedang dinventarisir, terdapat 66 layanan di seluruh dinas/instansi.

b) Ada kesadaran manfaat pengembangan TIK bagi pemerintah untuk dapat mengefisiensikan serta memudahkan dengan terpusat dan terintegrasi Untuk masyarakat menjadi lebih dekat dengan pemerintah dan terbuka dengan program serta kebijakan yang dapat diberikan masukan oleh masyarakat.

c) Beberapa UPTD yang ada di Kota Cimahi sudah mengembangkan aplikasi mereka sendiri. Contoh di Dinas Kesehatan Cimahi rata-rata sudah melalui proses online dari pendaftaran sampai ke pemeriksaan, tetapi masih ada kendala misal SDM masih kurang.

\section{Kota Banjar}

a) Sudah ada struktur organisasi yang efektif (organisasi yang mengelola TIK disusun berdasarkan Peraturan Daerah Kota Banjar Tahun 2016 mengenai pembentukan dan susunan perangkat darah, berdasarkan Perda tersebut terdapat Perumpunan Dinas Tipe C, Dinas Komunikasi, Informatika, Persandian dan Statistik menyelenggarakan urusan pemerintahan bidang komunikasi dan informatika, a) Kota Banjar sudah terpasang 62 unit menara telekomunikasi dari berbagai penyelenggara

telekomunikasi tetapi masih ada beberapa wilayah yang masih belum terlayani, contoh: wilayah perbatasan: Cimaranggas, Pamarican.

b) Saat ini, PD membeli jasa internet masing-masing, belum terintegrasi. Rencananya di tahun 2018, langkah pertama dengan a) Banjar sudah memiliki aplikasi, salah satunya aplikasi untuk perencanaan (SIMDA).

b) Ada beberapa dinas yang aplikasi sudah given dari pusat, misal untuk sistem data kependudukan berdasarkan NIK, sistem sudah online.

c) Sistem informasi di beberapa dinas sudah ada. Ada beberapa tidak secara langsung berkaitan dengan pelayanan masyarakat. Contoh Dinkes : Sudah ada 18 item yang terkait dengan sistem- 


\section{Gambaran Kesiapan}

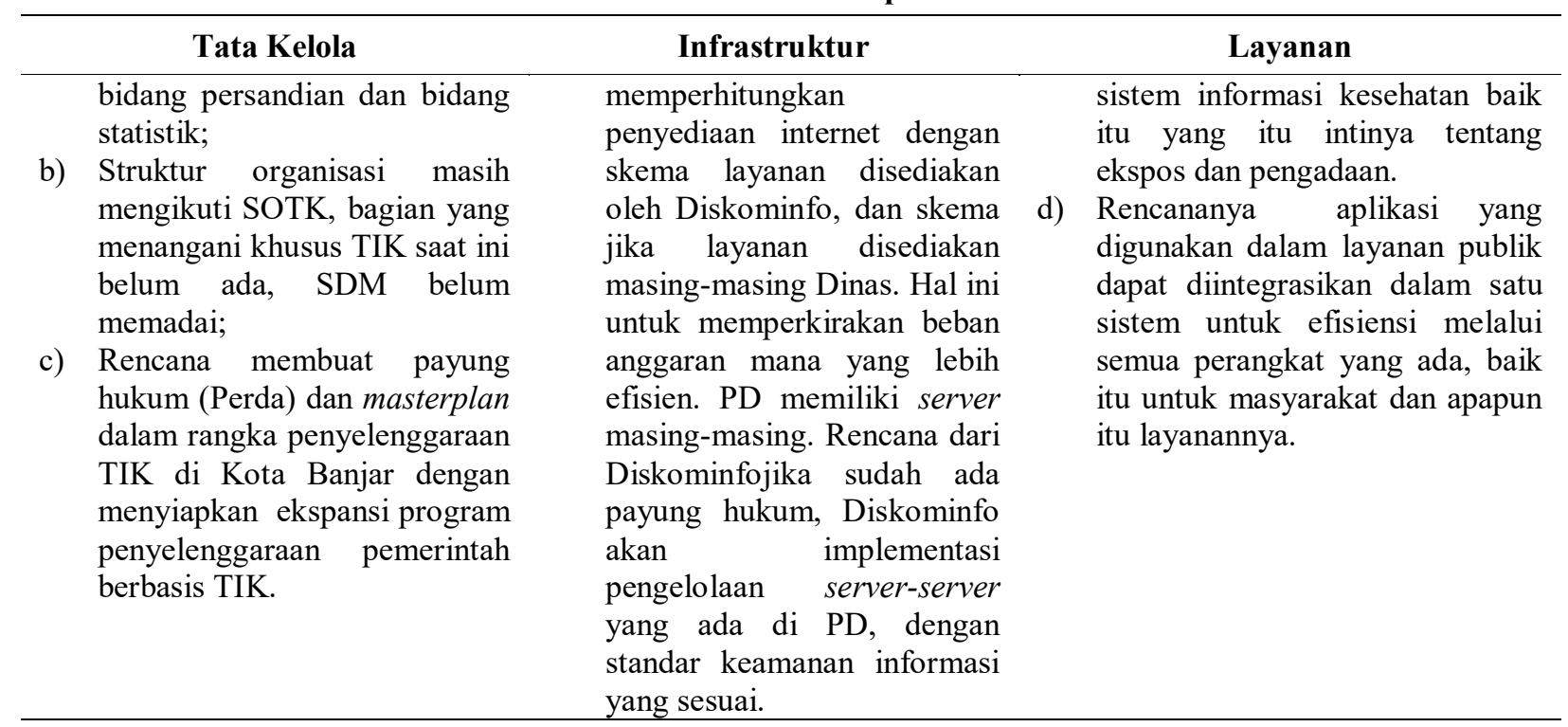

\section{Kabupaten Cirebon}

a) Sudah ada payung hukum yang berkaitan dengan pembentukan bagian yang mengelola TIK di dinas-dinas Kabupaten Cirebon. Dinas Komunikasi dan Informatika Kabupaten Cirebon dibentuk berdasarkan Peraturan Bupati Cirebon Nomor 61 Tahun 2016 tentang Organisasi dan Tata Kerja Dinas Daerah Kabupaten Cirebon.

b) INBUP Nomor 1 Tahun 2016 tentang Pendistribusian dokumen menggunakan e-mail resmi di lingkup Pemerintah Kabupaten Cirebon.

c) INBUP Nomor 3 Tahun 2017 tentang Tata Kelola Sistem Informasi dan Pusat Data di Lingkup Pemerintah Daerah Kabupaten Cirebon. Serta SK Bupati mengenai TIM Teknis TIK, dan yang lainnya.

d) Beberapa dinas masih menggunakan regulasi dari pusat/kementerian contoh: Disdukcapil Permendagri Nomor 61 Tahun 2015 untuk pemanfaatan data.

e) Blueprint pengembangan $e$ government. tahun depan akan dilakukan kajian perencanaan Ekosistem TIK Smart Regency. Untuk beberapa dinas menggunakan masterplan dari kementerian masing-masing seperti Disdukcapil: masterplan TIK untuk pengelolaan TI dari Kemendagri. a) Jaringan pusat perkantoran sepenuhnya menggunakan fiber optic;

b) Jaringan Kecamatan menggunakan Radio Wireless / WAN, dan direncanakan akan menjangkau hingga ke tingkat desa.

c) Jaringan intra dan antarSKPD menggunakan fiber optic dan WAN dan dibagi dalam clustering yang ditetapkan dalam topologi jaringan di lingkup Pemerintah Kabupaten Cirebon sesuai dengan Keputusan Bupati Cirebon No. 489/Kep.656-

kominfo/2017. a) Sudah ada layanan publik secara online terutama untuk kependudukan

b) Gambaran layanan publik menggunakan identitas tunggal belum optimal digunakan karena rules pemerintah pusat bahwa data NIK tidak dapat digunakan pada aplikasi lain kecuali atau izin pemerintah pusat. Sementara dinas-dinas lain seperti Disdukcapil semua aplikasi standarnya NIK.

c) Analytical tools hanya digunakan pada sistem informasi eksekutif SIE pada SIPKD. 


\section{Gambaran Kesiapan}

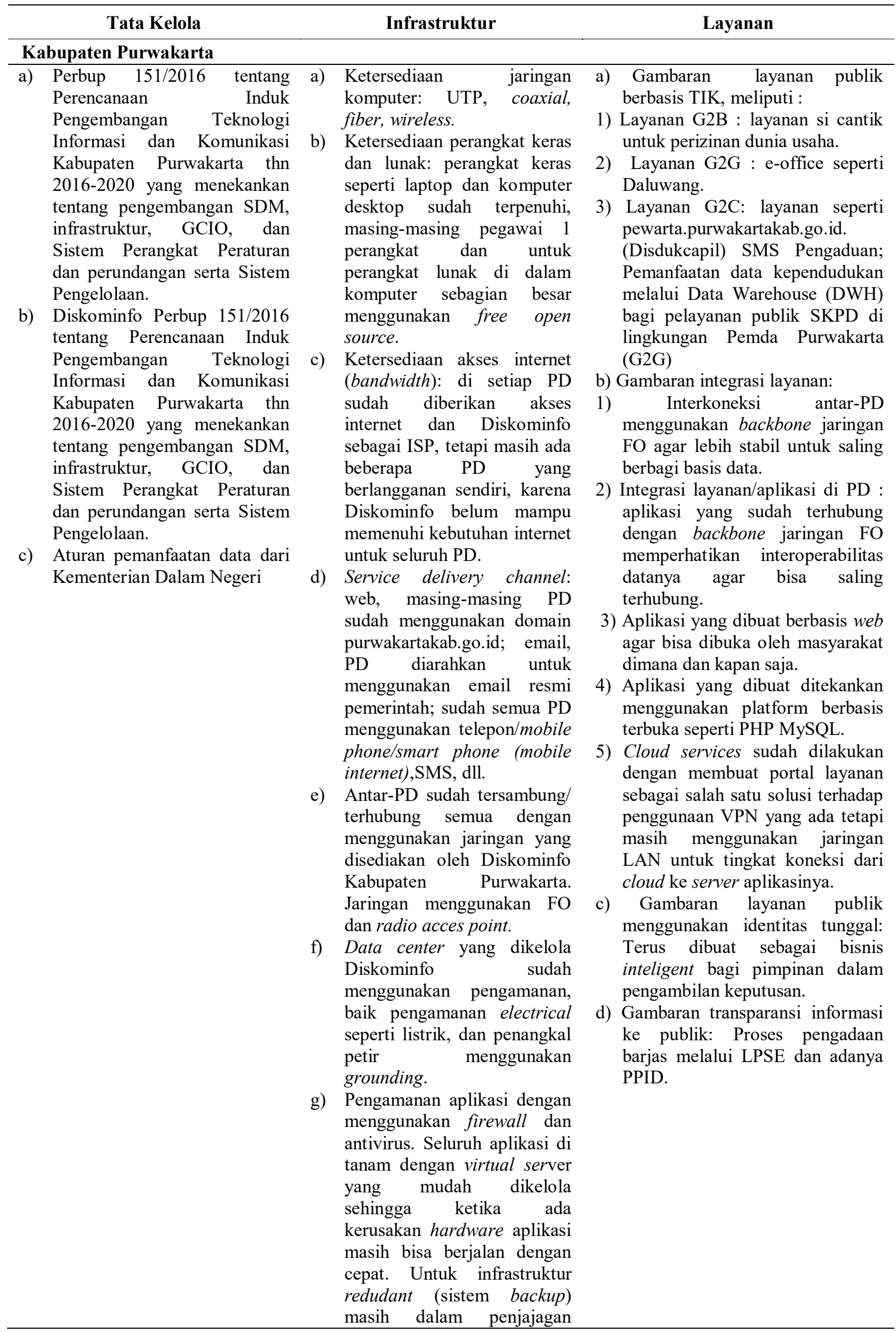




\section{Gambaran Kesiapan}

Tata Kelola

Infrastruktur

Layanan

untuk diletakkan di dalam

satu provider yang ada di

Kabupaten Purwakarta yang

memiliki standar disaster

recovery center yang baik.

h) Inventaris Infrastruktur TIK

Manajemen aset masih

manual pendataannya.

Berkaitan dengan

inventarisasi aset yang ada

dan keterkaitan dengan usia

hardware itu sendiri, dan

berkaitan dengan bentuk

pertanggungjawaban

administrasi pemerintahan.

\section{Kota Bogor}

a) Kota Bogor terpilih dari 100 kab/kota, dan merupakan salah satu dari 25 kota/kab (Tahap I) di tahun 2017 yang mendapatkan pendampingan smart city melalui penandatangan $\mathrm{MoU}$ dengan Kementerian Kominfo. Oleh karena itu perlu berkolaborasi dengan kab/kota lain. Di tahun 2017 juga mulai menyusun rencana/masterplan IT smart city, dan mulai menginventarisi semua keperluan/kebutuhan (aplikasi di dinas-dinas).

b) Hampir semua PD membangun sendiri-sendiri aplikasinya, karena memang belum ada peraturan yang mewajibkan bahwa itu harus oleh Diskominfo. a) Untuk infrastruktur sudah pakai FO, jaringan bebagai PD cukup kuat karena bandwidth cukup kuat di berbagai PD

b) Untuk Kota Bogor mungkin dapat dibilang memiliki infrastruktur yang yang lebih baik dibandingkan kota/kab. lain di Jawa Barat. Dapat dikatakan, Kota Bogor sudah siap dari infrastruktur secara fisik, software, sistem, semua sudah siap bahkan termasuk orangnya (SDM). Namun perlu diperhatikan bagaimana implementasi dan pengelolanya. a) Sudah dibangun sistem TIK untuk mendukung Bogor menjadi smart city, salah satunya sistem informasi rujukan, sistem tersebut sudah terintegrasi dengan rumah sakit - rumah sakit yang ada di Kota Bogor. Sudah dibangun Sistem Puskesmas (Sispus) sejak tahun 2014 dan aplikasi Picare, yaitu merekam pasien-pasien BPJS yang datang ke Puskesmas untuk membayar kredit.

b) Ada layanan SMS (dari pusat), berisi pesan-pesan kesehatan untuk ibu hamil di Kota Bogor. Aplikasi bombastis (pelaporan jentik DBD), SiHA (Sistem informasi HIV/AIDS), dan Sistem pendaftaran SIP (Izin Praktek Dokter).

c) Bapeda mempunyai sistem perencanaan untuk Kota Bogor terkait dengan program/kegiatan, hasil dari pengembangan dari Diskominfo terkait e-gov, implementasinya baru dua-tiga tahun.

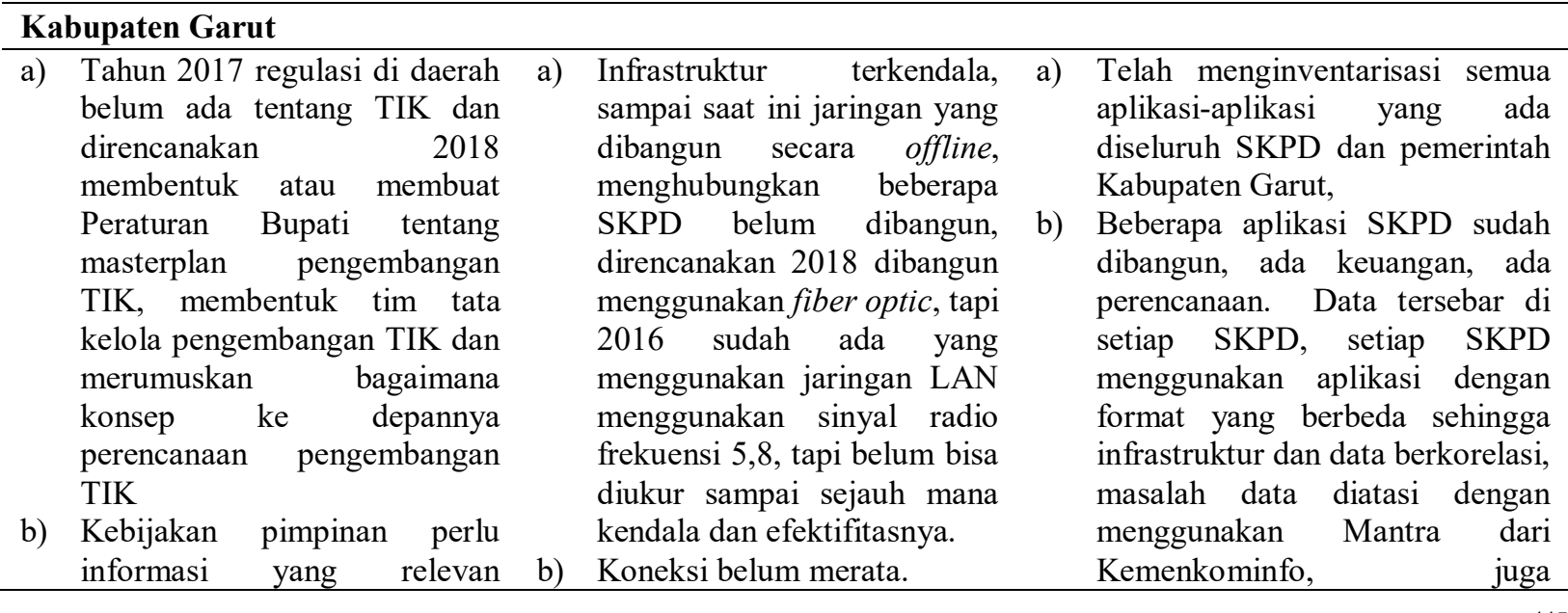




\begin{tabular}{|c|c|c|c|c|}
\hline \multicolumn{5}{|c|}{ Gambaran Kesiapan } \\
\hline & Tata Kelola & Infrastruktur & & Layanan \\
\hline c) & $\begin{array}{l}\text { mendukung untuk keputusan, } \\
\text { informasi yang relevan itu } \\
\text { harus diolah dari data yang } \\
\text { berkualitas dan baik, oleh } \\
\text { karena itu perlu integrasi data. } \\
\text { Dari sisi tata kelola, secara } \\
\text { manual semua instansi sudah } \\
\text { terhubung, tetapi kalau secara } \\
\text { digital belum. } \\
\text { Secara dokumentasi dan SOP } \\
\text { dinas mempunyai kurang lebih } \\
\text { sekitar 12 layanan publik, } \\
\text { misalnya diadopsi ke dalam } \\
\text { TIK merasa kesulitan, karena } \\
\text { ada Peraturan yang } \\
\text { mempersyaratkan begitu } \\
\text { banyak item-item yang harus } \\
\text { dipenuhi sehingga rasanya } \\
\text { untuk digitalisasi saat ini } \\
\text { belum dapat dilakukan. }\end{array}$ & & c) & $\begin{array}{l}\text { menggunakan aplikasi dari } \\
\text { provinsi. Untuk korelabilitas } \\
\text { data dari masing-masing SKPD. } \\
\text { Ada banyak aplikasi, apakah itu } \\
\text { aplikasi yang dibangun sendiri } \\
\text { oleh dinas ataupun aplikasi yang } \\
\text { itu merupakan pemberian dari } \\
\text { pusat. Akibatnya karena } \\
\text { banyaknya aplikasi-aplikasi } \\
\text { tersebut, ada aplikasi yang masih } \\
\text { bisa terus berjalan, ada aplikasi } \\
\text { yang mati suri. }\end{array}$ \\
\hline
\end{tabular}

Sumber: Olahan Wawancara, 2017.

\section{Gambaran Kesiapan Kota Cimahi Menuju Jabar Smart Province (JSP)}

Kota Cimahi sudah memiliki payung hukum untuk melaksanakan implementasi TIK melalui Pedoman Pengembangan $e$ government di Lingkungan Pemerintah Kota Cimahi dan turunannya. Untuk penerapan e-gov di Kota Cimahi berawal dari Cimahi Cyber dari tahun 2002. Rencana Pembangunan Jangka Menengah Daerah (RPJMD) Kota Cimahi Tahun 2012 - 2017; Rencana Pembangunan Jangka Panjang Daerah (RPJP) Kota Cimahi Tahun 2005 2025; Pedoman Pengembangan $e$ government di Lingkungan Pemerintah Kota Cimahi; Keputusan Walikota Cimahi tentang Pembentukan Tim Informasi Teknologi (IT) Kota Cimahi; Kebijakan Tata Kelola Pengamanan Data Center; Kebijakan Tata Kelola Aplikasi $e$ government; Kebijakan Tata Kelola dan Integrasi Data; persiapan adopsi sistem manajemen keamanan informasi berbasis ISO 27001; dokumen perencanaan sistem keamanan jaringan berbasis firewall. Dengan adanya kebijakan yang jelas, implementasi TIK di Kota Cimahi berjalan baik.

Untuk infrastuktur Diskominfo mengawal Perangkat Daerah (PD) (tidak sendiri-sendiri) sudah terintegrasi, server116 server PD di data center Diskominfo. Untuk pengembangan aplikasi diarahkan kepada penggunaan data secara bersama-sama (terintegrasi). Sudah terpusat dan beberapa terintegrasi, sisanya sedang dinventarisir, 66 layanan di seluruh dinas/instansi layanan. Beberapa PD sudah memiliki aplikasi/layanan, baik yang sudah terintegrasi dari pusat dan masing-masing PD.

Dari gambaran tata kelola, infrastruktur, dan layanan di Kota Cimahi, Cimahi siap menuju JSP. Dari sisi tata kelola, Cimahi memiliki regulasi dan kebijakan yang sesuai dalam impelementasi TIK, dari sisi infrastruktur sudah terpusat dan terintegrasi, dan dari sisi layanan memiliki aplikasi yang sesuai dengan kebutuhan baik itu untuk pemerintahan dan juga untuk layanan ke masyarakat. Mempunyai komitmen penuh dalam mengembangkan layanan berbasis TIK walaupun pengembangan antarlayanan masih ada yang dilakukan secara terpisah. Pada tingkat ini, inisiatif masih dilakukan oleh struktur departemen/dinas sebagai serangkaian proyek terpisah dengan dinas/departemen lain. Karakteristik dari kategori ini adalah sudah mulai dilakukan sharing data. 


\section{Gambaran Kesiapan Kota Banjar Menuju Jabar Smart Province (JSP)}

Kota Banjar sedang menyiapkan diri utamanya dari tata kelola yang menjadi dasar pelaksanaan implementasi TIK. Dengan adanya dasar hukum yang jelas, rencana detil akan disusun melalui masterplan TIK. Untuk infrastruktur masih sendiri-sendiri, belum terintegrasi. Untuk layanan, beberapa PD sudah memiliki aplikasi/layanan, baik yang sudah terintegrasi dari pusat dan masing-masing PD.

Pengembangan daerah perbatasan
perlu memperhatikan wilayah yang penerimaan sinyalnya kurang. Perbatasan merupakan daerah etalase provinsi sehingga dalam menuju JSP perlu dibantu wilayah dalam pengembangan TIK.

Dari gambaran tata kelola, infrastruktur, dan layanan di Kota Banjar, Kota/Kabupaten sudah melakukan inisiatif untuk mengembangkan layanan berbasis TIK walaupun pengembangan masih dilakukan secara parsial. Karakteristik dari kategori ini adalah adanya inisiatif sharing data yang masih dilakukan secara parsial.

\section{Gambaran Kesiapan Kabupaten Cirebon Menuju Jabar Smart Province (JSP)}

Kabupaten Cirebon sudah memiliki kebijakan terkait TIK melalui INBUP No. 1 Tahun 2016 tentang Pendistribusian dokumen menggunakan e-mail resmi di lingkup Pemerintah Kabupaten Cirebon. INBUP Nomor 3 tahun 2017 tentang Tata Kelola Sistem Informasi dan Pusat Data di Lingkup Pemerintah Daerah Kabupaten Cirebon. Serta SK Bupati mengenai TIM Teknis TIK, dan yang lainnya. Langkah ini dilakukan sebagai upaya untuk mengarahkan implementasi TIK di Kabupaten Cirebon.

Dari sisi infrastruktur seperti jangkauan akses, kapasitas jaringan, pengguna internet, jaringan antar-PD, dan keamanan informasi secara umum menurut dinas-dinas yang menjadi informan penelitian, sudah didukung dengan infrastruktur yang memadai, hanya masih diperlukan integrasi secara utuh.

Dari sisi layanan sudah banyak layanan berbasis TIK yang dibuat oleh
Diskominfo, dan Dinas Dukcapil, serta Dinas Koperasi dan UMKM yang tujuan utamanya adalah untuk mempermudah pemberian layanan ke masyarakat. Ada pemikiran yang muncul dari Kabupaten Cirebon bahwa TIK hanya sebagai alat, sehingga dibutuhkan kolaborasi bersama serta proses edukasi untuk masyarakat harus berjalan secara sehingga masyarakat bisa berpikir secara kreatif dan TIK menghasilkan sesuatu yang bermanfaat. Masih ada persepsi yang berbeda-beda berkaitan dengan layanan publik secara digital dan belum ada kolaborasi. Dengan TIK masyarakat diharapkan bisa kreatif, inovatif, dan berkarakter serta bisa mendapatkan nilai tambah dari internet itu sendiri.

Dari gambaran tata kelola, infrastruktur, dan layanan di Kabupaten Cirebon (Tabel 6), Pemerintah Kabupaten Cirebon sudah siap dalam menyongsong JSP, hal tersebut terlihat dari sudah adanya komitmen penuh dalam mengembangkan layanan berbasis TIK walaupun pengembangan antarlayanan masih dilakukan secara terpisah oleh masingmasing PD. Karakteristik dari kategori ini adalah sudah mulai dilakukan sharing data.

\section{Gambaran Kesiapan Kota Purwakarta Menuju Jabar Smart Province (JSP)}

Kota Purwakarta sudah memiliki kebijakan terkait TIK melalui Perbup No. 151 Tahun 2016 tentang Perencanaan Induk Pengembangan Teknologi Informasi dan Komunikasi Kabupaten Purwakarta tahun 2016-2020 yang menekankan tentang pengembangan SDM, infrastruktur, GCIO, dan Sistem Perangkat Peraturan dan perundangan serta Sistem Pengelolaan.

Dari sisi infrastruktur, seluruh OPD terhubung dengan menggunakan jaringan antar-PD yang dikelola oleh Diskominfo Kabupaten Purwakarta. Untuk jaringan sampai pertengahan tahun 2017 masih kombinasi antara jaringan Fiber Optik (FO) dengan radio acces point, akan tetapi nanti akan diganti seluruhnya dengan menggunakan jaringan FO. Dari sisi layanan sudah sudah ada beberapa layanan publik berbasis TIK yang dibuat oleh Pemkab 
Purwakarta, dan layanan untuk publik yang terintegrasi.

Dari gambaran tata kelola, infrastruktur dan layanan di Kabupaten Purwakarta (Tabel 6), Pemerintah Kabupaten Purwakarta sudah mulai melakukan inisatif untuk mengembangkan layanan berbasis TIK walaupun pengembangan masih dilakukan secara parsial. Hal ini terlihat dari sisi tata kelola yang mana masing-masing OPD masih menggunakan regulasi yang berbeda-beda dan adanya sharing data yang dilakukan masih secara parsial, sehingga bentuk/jenis layanan yang berbasis TIK juga masih dilakukan belum terintegrasi.

\section{Gambaran Kesiapan Kota Bogor Menuju Jabar Smart Province (JSP)}

Di sisi tata kelola, kesiapan Kota Bogor antara lain: sudah dimulai penyusunan rencana/masterplan IT dan inventarisasi kebutuhan aplikasi PD. Telah ada kerjasama dengan Kementerian Kominfo perihal smart city. Dengan adanya Perwali dapat menjadi dasar regulasi untuk pemanfaatan data kependudukan.

Di sisi infrastruktur: memiliki infrastruktur yang cukup untuk berkontribusi bagi smart city, memiliki jaringan bandwidth yang cukup kuat antar-PD. Sekolah-sekolah dan Puskesmas sudah memiliki sistem TIK di bawah dinas terkait.

Di sisi layanan: sudah memiliki aplikasi-aplikasi yang digunakan di masingmasing dinas terkait bidangnya, direncanakan akan dilakukan integrasi aplikasi-aplikasi antar-PD dan penggunaan data yang terpusat.

Dari gambaran tata kelola, infrastruktur dan layanan di Kabupaten, Pemerintah Kota Bogor dinilai siap dalam menyongsong smart province, dilihat dari sisi tata kelola yang memperhatikan pengembangan TIK dan pemanfaatan data. Dari sisi infrastruktur, cukup baik dalam mendukung layanan-layanan publik berbasis TIK dan online, yang sampai ke masyarakat.

\section{Gambaran Kesiapan Kabupaten Garut} Menuju Jabar Smart Province (JSP)
Kesiapan Kab. Garut menuju JSP di sisi tata kelola, yaitu: merencanakan membuat regulasi, Peraturan Bupati mengenai pengembangan TIK, membentuk tim tata kelola TIK, dan merumuskan konsep dan pengembangan TIK (masterplan TIK) di Tahun 2018. Sudah memiliki dokumentasi dan SOP untuk pelayanan publik. Terdapat aturan pusat yang tidak sejalan dengan dengan kebijakan daerah. Belum ada prioritas pengembangan SDM dan kerjasama antar-kementerian.

Dari sisi infrastruktur: sudah adanya jaringan LAN yang menghubungkan PD, rencana akan dibangun jaringan menggunakan FO Pada tahun 2018. Namun koneksi belum merata, perlu diperbaiki agar mudah diakses di Internet.

Dari sisi layanan: sudah menerapkan TIK untuk beberapa layanan publik, mis: website, SMS broadcast. Sudah inventarisasi aplikasi-aplikasi seluruh PD di lingkungan pemerintahan. Sudah menggunakan Mantra dari Kemenkominfo, juga menggunakan aplikasi dari pemeritah provinsi. Ada banyak aplikasi, apakah itu aplikasi yang dibangun sendiri oleh dinas ataupun aplikasi yang itu merupakan pemberian dari pusat. Akibatnya karena banyaknya aplikasi-aplikasi tersebut, ada aplikasi yang masih bisa terus berjalan, ada aplikasi yang mati suri.

Dari gambaran tata kelola, infrastruktur dan layanan di Kabupaten Garut (Tabel 6), Kesiapan Pemerintah Kabupaten Garut dari sisi regulasi, tahun 2018 akan dibuat Perbup mengenai pengembangan TIK, sehingga di tahun 2017 dinilai belum cukup siap dari sisi regulasi terkait smart province. Di sisi infrastruktur, berdasarkan gambaran, Kabupaten Garut dinilai perlu untuk memfokuskan pada peningkatan infrastruktur dan sumber daya TIK yang dapat mendukung penerapan smart province. Pengembangan aplikasi, integrasi dan pemanfaatan data untuk mendukung smart province perlu ditingkatkan lagi.

\section{Kesiapan Daerah Menuju Jabar Smart Province \\ Jabar Smart Province merupakan insiatif Pemerintah Provinsi Jawa Barat}


yang diharapkan dapat mendorong pemanfaatan TIK dalam layanan pemerintah. Hal ini dalam praktiknya memerlukan perhatian dari banyak aspek. Dari sisi kesiapan daerah, enam daerah yang menjadi sampel penelitian menujukkan kesiapan dalam menyongsong Jabar Smart Province (JSP), namun dengan kategori yang berbeda-beda.

\section{Tabel 7}

Kesiapan Kota/Kabupaten

\begin{tabular}{|l|}
\hline Kota/Kabupaten \\
\hline Kota Banjar
\end{tabular}

Kota Cimahi

Kabupaten Cirebon

Kabupaten

Purwakarta

Kota Bogor

Kabupaten Garut

\section{PENUTUP}

\section{Simpulan}

Jabar Smart Province merupakan insiatif Pemerintah Provinsi Jawa Barat yang diharapkan dapat mendorong pemanfaatan TIK dalam layanan pemerintah. Hal ini dalam praktiknya memerlukan perhatian dari banyak aspek.
Dari sisi kesiapan daerah, enam daerah yang menjadi sampel penelitian menujukkan kesiapan dalam menyongsong Jabar Smart Province (JSP), namun dengan kategori yang berbeda-beda.

Kota Banjar sedang menyiapkan diri utamanya dari tata kelola yang menjadi dasar pelaksanaan implementasi TIK. Dengan adanya dasar hukum yang jelas, 
rencana detail akan disusun melalui masterplan TIK. Untuk infrastruktur masih sendiri-sendiri, belum terintegrasi. Untuk layanan, beberapa PD sudah memiliki aplikasi/layanan, baik yang sudah terintegrasi dari pusat dan masing-masing.

Kota Cimahi siap dengan tata kelola yang sudah implementasi, untuk infrastruktur sudah terintegrasi, serta sebagian layanan yang sudah terintegrasi dan inventarisasi layanan yang dilakukan. Mempunyai komitmen penuh dalam mengembangkan layanan berbasis TIK walaupun pengembangan antarlayanan masih ada yang dilakukan secara terpisah. Pada tingkat ini, inisiatif masih dilakukan oleh struktur departemen/dinas sebagai serangkaian proyek terpisah dengan dinas/departemen lain. Karakteristik dari kategori ini adalah sudah mulai dilakukan sharing data.

Pemerintah Kabupaten Cirebon sudah siap dalam menyongsong JSP. Hal tersebut terlihat dari sudah adanya komitmen penuh dalam mengembangkan layanan berbasis teknologi yang didukung dengan telah dikeluarkannya regulasi/kebijakan pengembangan pelayanan berbasis teknologi. Walaupun pengembangan antarlayanan masih dilakukan secara terpisah oleh masing-masing PD. Karakteristik dari tingkat kematangan ini adalah sudah mulai dilakukan sharing data.

Pemerintah Kabupaten Purwakarta sedang menyiapkan diri menuju JSP, terlihat dari sudah dimulainya melakukan inisiatif untuk mengembangkan layanan berbasis TIK walaupun pengembangan masih dilakukan secara parsial. Hal ini terlihat dari sisi tata kelola di mana masing-masing PD masih menggunakan regulasi yang berbedabeda dan belum adanya integrasi antar-PD sehingga pelayanan kepada publik juga masih dilakukan oleh masing-masing dinas. Dalam arti adanya sharing data yang dilakukan masih secara parsial, sehingga bentuk/jenis layanan yang berbasis TIK juga masih dilakukan belum terintegrasi.

Pemerintah Kota Bogor sudah siap menuju JSP. Hal tersebut ditandai dengan sudah adanya komitmen penuh dalam mengembangkan layanan berbasis TIK walaupun pengembangan antarlayanan masih dilakukan secara terpisah. Pada tingkat ini, inisiatif masih dilakukan oleh masing-masing dinas sebagai serangkaian proyek terpisah. Karakteristik dari tingkat kematangan ini adalah sudah mulai dilakukan sharing data.

Pemerintah Kabupaten Garut sedang dalam persiapan menuju Jabar Smart Province, terlihat dari sudah adanya inisiatif untuk mengembangkan layanan berbasis TIK walaupun pengembangan masih dilakukan secara parsial. Karakteristik dari tingkat kematangan ini adalah adanya sharing data yang dilakukan secara parsial.

Dengan adanya gambaran kesiapan daerah menuju JSP dapat menjadi informasi bagi pemerintah kota/kab. dan provinsi dalam menyelaraskan program-program yang dapat mendorong terwujudnya JSP.

\section{Saran}

Berdasarkan simpulan tentang kesiapan daerah menuju Jabar Smart Province (JSP), maka dapat direkomendasikan perlunya dilakukan pemetaan kekuatan dan arah perubahan dalam mempercepat daerah menuju JSP yang dilihat dari 3 aspek yakni: (1) Dari aspek tata kelola, antara provinsi dan daerah diperlukan koordinasi yang kuat, melalui pendekatan-pendekatan dan kewenangan yang dapat didiskusikan bersama. Pencapaian program-program memerlukan anggaran dan prioritas dari daerah, sehingga perlu ada perubahan untuk mendorong hal ini dengan mendorong e-leadership dalam artian komitmen pemerintah dapat menjadi pendorong positif dalam pencapaian tata kelola yang efektif. Mendorong penguatan kapasitas SDM menjadi hal penting untuk mendorong penguatan pencapaian semua aspek, usulan dari beberapa daerah untuk pengembangan insiatif TIK dibutuhkan SDM yang dapat memeiliki integritas dan kompetensi yang sesuai sehingga dibutuhkan apresiasi yang layak juga untuk penempatan SDM tersebut.

Kondisi pendampingan dan sosialisasi baik langsung dari pemerintah pusat, maupun dari Provinsi yang sudah dilakukan perlu ditingkatkan baik untuk PD-PD yang 
membutuhkan, utamanya PD yang berada pada tupoksi dalam mengawal pengembangan TIK, dan untuk PD-PD yang melakukan pengembangan layanan berdasarkan tupoksi mereka. Aspek berikutnya (2) dari aspek infrastruktur, dorongan untuk konektivitas antar-PD dan level lainnya menjadi pendorong yang perlu diarahkan sehingga implementasi pengembangan TIK di daerah dapat terlaksana. Bahkan terdapat usulan intranet, mulai dari antar-PD, sampai cakupan wilayahnya, dan diusulkan pengaturan internet publik dapat langsung diarahkan sesuai kebutuhan di daerah saja. (3) Dari aspek layanan, layanan dengan standar yang masih berbeda-beda perlu diarahkan untuk dapat dijembatani dengan platform yang sama, dan ke depannya diarahkan melalui SOP yang sesuai untuk pengembangan layanan TIK.

\section{DAFTAR PUSTAKA}

Abdurrahman, M.S. (2016) Jabar Bergegas Menjadi Smart Province. [Online]. 2016. Liputan6. Available from: https://www.liputan6.com/tekno/read/ 2672914/jabar-bergegas-menjadismart-province [Accessed: 15 January 2017].

Anthopoulos, L., Reddick, C., Giannakidou, I. \& Mavridis, N. (2015) Egovernment as an Innovative product: Theories and Case Study. In: Information and Communication Technologies in Public Administration. CRC Press. p.

Anthopoulos, L.G. \& Reddick, C.G. (2016) Smart City and Smart Government: Synonymous or Complementary? In: Proceedings of the 25th International Conference Companion on World Wide Web. 2016 International World Wide Web Conferences Steering Committee. pp. 351-355.

Bappenas (2011) Kebijakan dan Strategi Perkotaan Nasional (KSPN).

Barlow, M. (2015) Smart Cities, Smarter Citizens. O'Reilly Media, Inc.
Budhirianto, S. (2014) Pengembangan Jabar Cyber Province sebagai Media Informasi dan Komunikasi. Jurnal Penelitian Komunikasi. [Online] 17 (1), 55-68. Available from: doi:10.20422/jpk.v17i1.6

Diskominfo Provinsi Jabar (2014) Inovasi Jabar Cyber Province. [Online]. 2014. Available from: https://jabarprov.go.id/index.php/artik el/detail_artikel/121/2014/11/13/Inova si-Jabar-Cyber-Province [Accessed: 15 January 2017].

Diskominfo Provinsi Jabar (2017) Paparan Kepala Diskominfo Provinsi Jabar: Peran Integrasi e-Government menuju Smart Government.

Gil-Garcia, J.R., Zhang, J. \& Puron-Cid, G. (2016) Conceptualizing smartness in government: An integrative and multidimensional view. Government Information Quarterly. 33 (3), 524534.

Kementerian Kominfo (2015) Buku Putih TIK 2015. Jakarta, Badan Penelitian dan Pengembangan Sumber Daya Manusia.

Kementerian Kominfo (2016) Peraturan Menteri Komunikasi dan Informatika Republik Indonesia Nomor 13 Tahun 2016 Tentang Hasil Pemetaan Urusan Pemerintahan Daerah di Bidang Komunikasi dan Informatika.

Kumar, T.M.V. (2014) E-Governance for Smart Cities.

Mayangsari, L. \& Novani, S. (2015) Multistakeholder co-creation Analysis in Smart city Management: An Experience from Bandung, Indonesia. Procedia Manufacturing. [Online] 4 (Iess), 315-321. Available from: doi:10.1016/j.promfg.2015.11.046.

Nam, T. \& Pardo, T.A. (2011) Conceptualizing smart city with dimensions of technology, people, and institutions. ACM International Conference Proceeding Series. [Online] 282-291. Available from: doi:10.1145/2037556.2037602.

Pemprov Riau (2017) Riau Smart Province. [Online]. 2017. Available from: http://diskominfotik.riau.go.id/?s=sma 
$\mathrm{rt}+$ province [Accessed: 2 February 2017].

Pemprov Sumatera Utara (2017) Sumut Smart Province. [Online]. 2017. Available from: http://smartprovince.sumutprov.go.id/ [Accessed: 2 February 2017].

PPN/Bappenas, K. (2015) Pengembangan Kota Cerdas di Indonesia. Direktur Perkotaan dan Perdesaan, Kementerian PPN/Bappenas.

Purnomo, F., Meyliana, . \& Prabowo, H. (2016) Smart City Indicators: A Systematic Literature Review. Journal of Telecommunication, Electronic and Computer Engineering (JTEC). 8 (3), 161-164.

Puslitbang PPI (2013) Laporan Akhir Studi Tingkat Kematangan (Maturity) Smart City Di Indonesia.

Salsabila, S. (2015) Analisis QFD Pada Layanan Customer Representative Mobile Community Access Point (MCAP) Dinas Kominfo Provinsi Jawa Barat. [Online]. 2015. Available from: https://openlibrary.telkomuniversity.ac .id/pustaka/101916/analisis-qfd-padalayanan-customer-representativemobile-community-access-point-mcap-dinas-kominfo-provinsi-jawabarat.html [Accessed: 24 January 2017].

SCCIC (2018) GARUDA SMART CITY MODEL. [Online]. 2018. Available from:

http://www.sccic.id/research/garudasmart-city-model/.

Scholl, H.J. \& Alawadhi, S. (2016) Creating Smart Governance: The key to radical ICT overhaul at the City of Munich. Information Polity. [Online] 21 (1), 21-42. Available from: doi:10.3233/IP-150369.

Stimmel, C.L. (2016) Building Smart Cities. CRC Press.

Utomo, C.E.W.; M.H. (2016) Strategi Pembangunan Smart City dan Tantangannya bagi Masyarakat Kota. Jurnal Strategi dan Bisnis. 4 (2), 159176. 